\title{
Post-traumatic chronic bone and joint infection caused by Butyricimonas spp, and treated with high doses of ertapenem administered subcutaneously in a 30-year-old obese man
}

\author{
T Ferry, $^{1,2,3}{ }^{2}$ Laurent, ${ }^{1,2,3}$ P Ragois, $^{4}{ }^{C}$ Chidiac, $^{1,2,3}$ on behalf of the Lyon BJI \\ Study Group
}

${ }^{1}$ Service de Maladies Infectieuses et Tropicales, Hôpital de la Croix-Rousse, Hospices Civils de Lyon, Lyon, France

${ }^{2}$ Université Claude Bernard Lyon 1, Lyon, France ${ }^{3}$ Centre International de Recherche en Infectiologie (CIRI), Lyon, France

${ }^{4}$ Centre Orthopédique de Dracy-le-Fort, Dracy-le-Fort, France

\section{Correspondence to} Dr T Ferry,

tristan.ferry@univ-lyon1.fr

Accepted 26 September 2015

CrossMark

To cite: Ferry $T$, Laurent $F$, Ragois P, et al. BMJ Case Rep Published online:

[please include Day Month Year] doi:10.1136/bcr-2015212359

\section{DESCRIPTION}

An obese but otherwise healthy 30-year-old man presented with septic pseudarthrosis following a post-traumatic open radial fracture. Three months earlier, the patient had been involved in a truck accident and suffered a distal open radial fracture associated with compartment syndrome (figure 1A). Primary management consisted of wound debridement, fasciotomy, stabilisation with external fixation and antibiotic prophylaxis with amoxicillin-clavulanate. The wound healed after 1 month (figure 1B). Due to pseudarthrosis (figure $1 \mathrm{C}, \mathrm{D})$, the patient returned to the operating room for internal fixation. He did not have fever, and there was no local sign of inflammation and no fistula; C reactive protein was $<5 \mathrm{mg} / \mathrm{L}$. Internal fixation was not performed, as a bone abscess in the facture site was discovered. Surgical samples revealed Bacteroides vulgatus, Clostridium tertium and Butyricimonas spp in cultures. MRI revealed several abscesses in the radius (figure 1E). As the patient refused central vascular access, he received prolonged high doses of ertapenem subcutaneously ( $1 \mathrm{~g}$ two times a day) for 3 months, with metronidazole during the first month, followed by clindamycin. The ertapenem (diluted in $50 \mathrm{cc}$ of physiological serum) was infused subcutaneously by butterfly disposable needle in the lower quadrants of the abdomen and alternately on the anterior side of a thigh (figure 1F, G) during a 30-60 min gravity infusion. Arthrodesis was then performed and the outcome was favourable (figure $1 \mathrm{H}$ ).

Butyricimonas spp are normal inhabitants of the intestine in humans and animals. ${ }^{1}$ Bone and joint
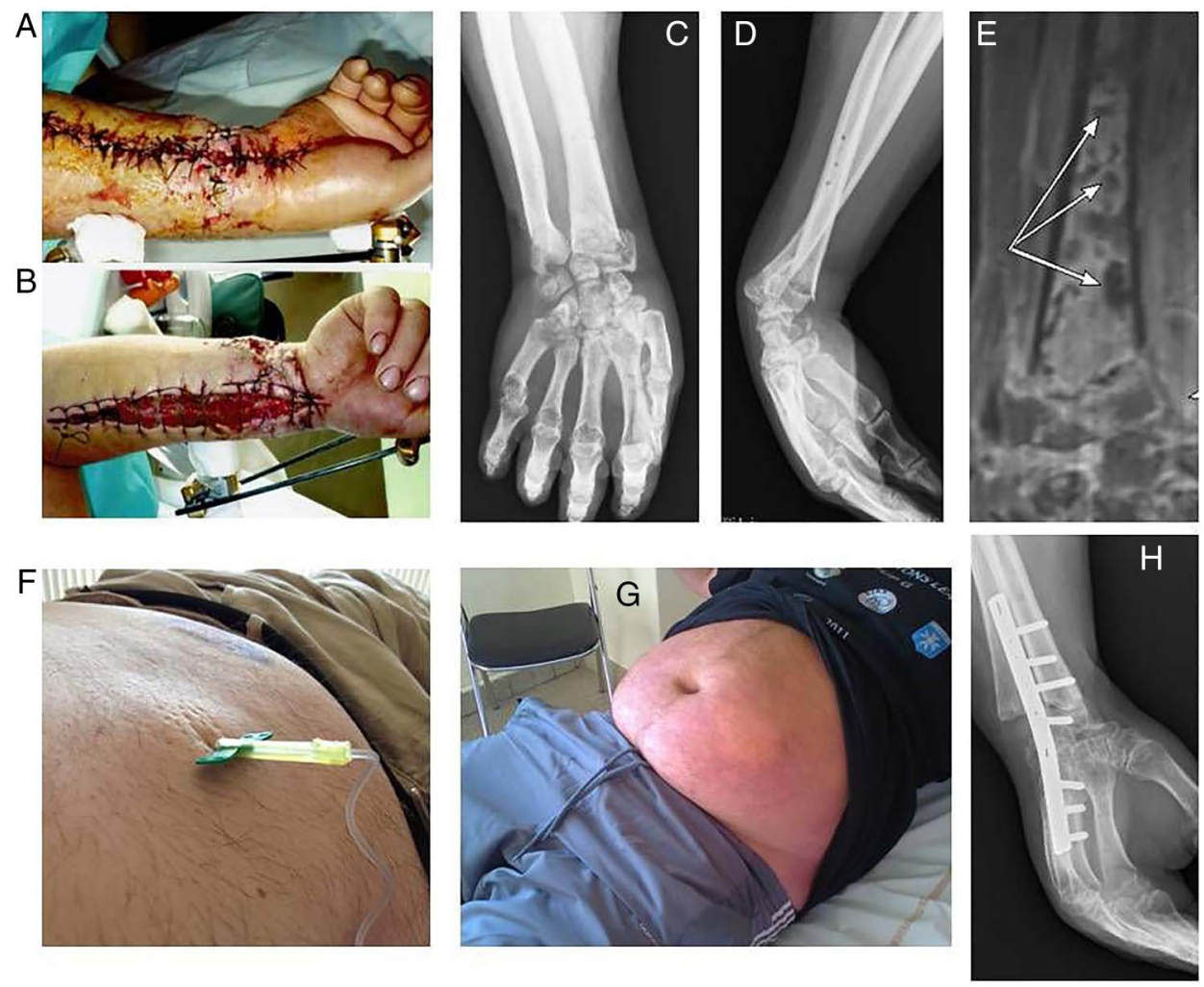

Figure 1 The patient with compartment syndrome following open radial fracture stabilised with external fixation (A). Favourable clinical aspect 1 month after fasciotomy (B). Radial pseudarthrosis (C) with subluxation (D). MRI revealing multiple intramedullary abscesses of the radius (E). Subcutaneous infusion of ertapenem using butterfly disposable needle $(F)$ with tumefaction immediately following the injection in the lower left abdominal quadrant (G). Arthrodesis and favourable outcome $(\mathrm{H})$ after 3 months of antimicrobial therapy. 
infection (BJI) caused by Butyricimonas has never been described. Prolonged ertapenem therapy administered subcutaneously could be useful for the treatment of anaerobic BJIs. ${ }^{2}$

\section{Learning points}

- Butyricimonas spp, a commensal anaerobe of the digestive tract, could be responsible for port-traumatic bone and joint infection.

- High doses of ertapenem administered subcutaneously are useful for the treatment of bone and joint infection due to anaerobic bacteria in patients refusing vascular access.

Acknowledgements Lyon Bone and Joint Infection Study Group: PhysiciansTristan Ferry, Thomas Perpoint, André Boibieux, François Biron, Florence Ader, Julien Saison, Florent Valour, Fatiha Daoud, Johanna Lippman, Evelyne Braun, Marie-Paule
Vallat, Patrick Miailhes, Christian Chidiac, Dominique Peyramond; SurgeonsSébastien Lustig, Philippe Neyret, Olivier Reynaud, Caroline Debette, Adrien Peltier, Anthony Viste, Jean-Baptiste Bérard, Frédéric Dalat, Olivier Cantin, Romain Desmarchelier, Thibault Vermersch, Michel-Henry Fessy, Cédric Barrey, Francesco Signorelli, Emmanuel Jouanneau, Timothée Jacquesson, Pierre Breton, Ali Mojallal, Fabien Boucher, Hristo Shipkov; Microbiologists — Frederic Laurent, François Vandenesch, Jean-Philippe Rasigade, Sophie Trouillet-Assant, Céline Dupieux; Nuclear Medicine-Isabelle Morelec, Marc Janier, Francesco Giammarile; PK/PD specialists-Michel Tod, Marie-Claude Gagnieu, Sylvain Goutelle; Clinical Research Assistant-Eugénie Mabrut.

Competing interests None declared.

\section{Patient consent Obtained.}

Provenance and peer review Not commissioned; externally peer reviewed.

\section{REFERENCES}

1 Sakamoto M, Tanaka Y, Benno Y, et al. Butyricimonas faecihominis sp. nov. and Butyricimonas paravirosa sp. nov., isolated from human faeces, and emended description of the genus Butyricimonas. Int I Syst Evol Microbiol 2014;64:2992-7.

2 Ferry T, Sénéchal A, Gagnieu MC, et al. Prolonged subcutaneous high dose (1 g bid) of ertapenem as salvage therapy in patients with difficult-to-treat bone and joint infection. J Infect 2012;65:579-82.

Copyright 2015 BMJ Publishing Group. All rights reserved. For permission to reuse any of this content visit http://group.bmj.com/group/rights-licensing/permissions.

BMJ Case Report Fellows may re-use this article for personal use and teaching without any further permission.

Become a Fellow of BMJ Case Reports today and you can:

- Submit as many cases as you like

- Enjoy fast sympathetic peer review and rapid publication of accepted articles

- Access all the published articles

- Re-use any of the published material for personal use and teaching without further permission

For information on Institutional Fellowships contact consortiasales@bmjgroup.com

Visit casereports.bmj.com for more articles like this and to become a Fellow 